\title{
Bio-Fertilizers via Co-Digestion: a Review
}

\section{Abdulwadud Yusuf Abdulkarim ${ }^{1}$, Surajudeen Abdulsalam ${ }^{1}$, Usman Aliyu El-Nafaty ${ }^{1}$, Idris Misau Muhammad ${ }^{1}$}

\author{
${ }^{1}$ Abubakar Tafawa Balewa University \\ Dass road, P. M. B. 0248, Bauchi, 740272, Nigeria
}

DOl: $10.22178 /$ pos.47-3

LCC Subject Category: QH301-705.5

Received 28.05.2019

Accepted 25.06.2019

Published online 30.06.2019

Corresponding Author: Abdulwadud Yusuf Abdulkarim aabdulwadud@atbu.edu.ng

(C) 2019 The Authors. This article is licensed under a Creative Commons Attribution 4.0 License (c) (1)

\begin{abstract}
In diversifying the economies of most oil producing countries especially in regions with arable lands, Agriculture becomes the next choice aside mineral deposits. This has led to a search for an alternative to inorganic fertilizers, the alternatives are the biofertilizers. The paper discussed the classification of the anaerobic co-digestion process based on the application of inoculants to the biodigester feedstock to speed up the digestion process and the absence of inoculants. Biodigester feedstock also looked at the various mechanisms in the digestion process which includes hydrolysis, acidogenesis, acetogenesis, and methanogenesis, the pathways were illustrated with chemical equations and various microorganisms that take part in the anaerobic process were mentioned and tabulated. The types of biofertilizers, merits, and demerits, the difference between biofertilizers and organic fertilizers were comprehensively discussed. Current trends on the application of the co-digestion technique to improve the yield, nutrient, and safety of biofertilizers and also the recent progression on the technique were mentioned.
\end{abstract}

Keywords: anaerobic; bio-fertilizers; co-digestion; digestates; inoculum.

\section{INTRODUCTION}

Anaerobic digestion (AD) is a complex biological process that converts organic materials to methane through four major steps: hydrolysis, acetogenesis, and methanogenesis by bacteria under poor or no oxygen conditions [5, 47].

The process of formation of bio-fertilizers is known as anaerobic digestion. Anaerobic digestion means the micro-organisms digest the food without oxygen [43]. As shown in the pictorial representation (Figure 1), it involves the controlled degradation of organic wastes in the absence of oxygen and in the presence of anaerobic microorganisms [4].

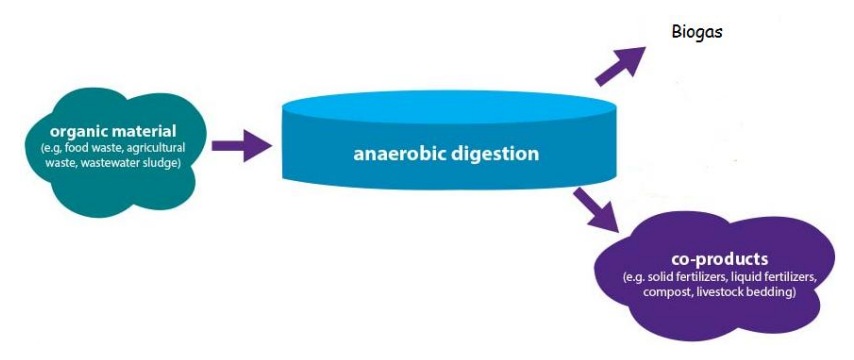

Figure 1 - Schematic representation of anaerobic digestion
Anaerobic digestion based on the techniques applied by various authors can be simply classified into two major classes: $\mathrm{AD}$ based on the use of inoculum and that with the absence of inoculum.

Anaerobic digestion with the use of inoculum. The startup of biodigesters involves the buildup of some consortium of microorganisms that help in the process of anaerobic digestion. These organisms are mostly available in the manures/animal wastes used as substrates. For a faster startup and a faster biogas build up, the methanogenic bacteria (methanobacteria) are isolated and cultured to adapt to the feed and the operating conditions of the biodigester, this is known as inoculum [2].

Many works have been conducted on the importance of applying inoculum. It was observed that the inoculum to biogas production rate (which is a precursor for $\mathrm{AD}$ progression) increased with increase in inoculum to substrate ratio [25], also application of inoculum may lead to rapid initial biogas production in the digester due to a high population of methanogens and availability of substrates [6]. The use of inoculum (palm oil mill effluent) also reduced the startup period and in- 
creased the biodigester performance and stability [38].

Although the use and application of inoculum have the advantages stated above, the cost of preparing and culturing the inoculum remains a major setback to the method when compared with AD without inoculum.

Anaerobic digestion without inoculum. This class of anaerobic digestion is the most popularly applied in most bioreactor plants. It is very cheap, easy to start and does not involve too many technicalities. It is mostly applied when the substrate to be used for $\mathrm{AD}$ is more of ruminants and dairy manure. When the feedstock is made up of agricultural wastes, there may be a need for the use of inoculum to speed up the startup time and to reduce the retention period. The major demerits of this method include a slower startup and higher retention periods [48].

Anaerobic digestion consists of four general processes namely; hydrolysis, acidogenesis, acetogenesis, and methanogenesis. Figure 2 shows the pathways of $\mathrm{AD}$.

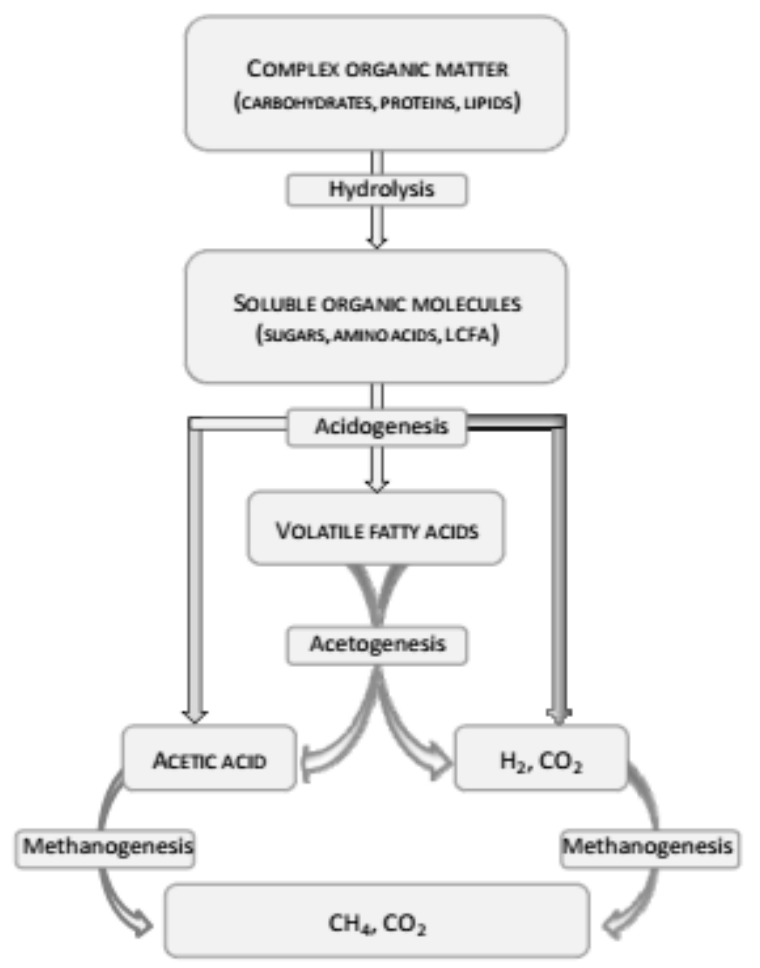

Figure 2 - Pathways of Anaerobic Digestion [31]

Hydrolysis. Hydrolysis means the cleavage of bonds by the addition of water molecules. This is the first stage in $\mathrm{AD}$ and it is one of the most important stages. Large organic molecules may be too complex to be directly used by microorgan- isms as a substrate/food source, thus for biodegradation to occur certain microorganisms secrete different types of enzymes, called extracellular enzymes, which help in solubulisation and break down of the complex molecules into smaller and easily accessible substrates that the microorganism can then assimilate and use as source of energy and nutrition $[1,29]$. These microorganisms form a community of various bacterial groups, some of which are: Bacteriodes, Clostridium, and Acetivibrio [17]. Some of these organisms have several enzymes combined into celluloses -large, stable, multi-enzyme complexes specialized in the adhesion to and degradation of cellulose that reside with protuberances visible on the cell surface. There are situated on the organism's cell wall [17].

Factors that affect hydrolysis in AD include; particle size, $\mathrm{pH}$, production of enzymes and diffusion and adsorption of enzymes to particles. During hydrolysis, carbohydrates, proteins, and fats are converted to smaller compounds (monomers and dimers): sugars, amino acids, and fatty acids. Hydrolysis is usually the rate-limiting step in biodigestion. An illustration of a hydrolysis reaction where organic waste is broken down into simple sugar is shown in Equation 1 [40].

$$
\mathrm{C}_{6} \mathrm{H}_{10} \mathrm{O}_{5}+2 \mathrm{H}_{2} \mathrm{O} \stackrel{\text { Enzymes }}{\longrightarrow} \mathrm{C}_{6} \mathrm{H}_{12} \mathrm{O}_{6}
$$

Acidogenesis. This is the second stage in AD process. It is also referred to as fermentation. Here the products of hydrolytic phase are further degraded into volatile fatty acids (VFAs), short chain organic acids (such as butyric acids, propionic acids, acetic acids), alcohols, hydrogen and carbon dioxide by a heterogeneous microbial population mostly the facultative and obligatory anaerobic bacteria $[1,29,40]$. The hydrogen, carbon dioxide, acetic acid and water will skip to the third stage, acetogenesis, and be utilized directly by the methanogenic bacteria in the final stage. Equations 2-4 represent three typical acidogenesis reactions where glucose is converted to ethanol, propionic and acetic acid, respectively [40].

$$
\begin{aligned}
& \mathrm{C}_{6} \mathrm{H}_{12} \mathrm{O}_{6} \stackrel{\text { Enzymes }}{\longrightarrow} 2 \mathrm{CH}_{3} \mathrm{CH}_{2} \mathrm{OH}+2 \mathrm{CO}_{2} \\
& \mathrm{C}_{6} \mathrm{H}_{12} \mathrm{O}_{6}+2 \mathrm{H}_{2} \stackrel{\text { Enzymes }}{\longrightarrow} 2 \mathrm{CH}_{3} \mathrm{CH}_{2} \mathrm{COOH}+ \\
&+ 2 \mathrm{H}_{2} \mathrm{O}
\end{aligned}
$$




$$
\mathrm{C}_{6} \mathrm{H}_{12} \mathrm{O}_{6} \stackrel{\text { Enzymes }}{\longrightarrow} 3 \mathrm{CH}_{3} \mathrm{COOH}
$$

Acetogenesis. The second to the last phase of $\mathrm{AD}$ is the acetogenic process. Here two groups of microorganisms play a key role: the acetogenic bacteria produce hydrogen binding using the products of acidogenic bacteria as sublayer thus giving rise to acetate, hydrogen, and carbonic anhydride and then also the homoacetogene bacteria that synthesize acetate starting from carbonic anhydride and hydrogen [12]. $\mathrm{H}_{2}$-producing acetogenic bacteria are capable of producing acetate and $\mathrm{H}_{2}$ from higher fatty acids. $\mathrm{H}_{2}$ produced, severely inhibits the growth of these strains as the reaction will only occur if the hydrogen partial pressure is low enough to thermodynamically allow the conversion of all the acids [40], thus coculture techniques are applied by incorporating hydrogen scavenging bacteria such as methanogens and sulfate-reducing bacteria which may, therefore, facilitate elucidation of the biochemical breakdown of fatty acids [10]. Equation 5 represents the conversion of propionate to acetate, only achievable at low hydrogen pressure while equations 6 and 7 illustrate the conversion of glucose and ethanol to acetate during the third stage of anaerobic fermentation [40].

$$
\begin{aligned}
& \mathrm{CH}_{3} \mathrm{CH}_{2} \mathrm{COO}^{-}+3 \mathrm{H}_{2} \mathrm{O} \stackrel{\text { Enzymes/Low } \mathrm{H}_{2} \text { Pressure }}{\longleftrightarrow} \\
& \mathrm{CH}_{3} \mathrm{COO}^{-}+\mathrm{H}^{+}+\mathrm{HCO}_{3}^{-}+3 \mathrm{H}_{2} \\
& \mathrm{C}_{6} \mathrm{H}_{12} \mathrm{O}_{6}+2 \mathrm{H}_{2} \mathrm{O} \stackrel{\text { Enzymes }}{\longrightarrow} \\
& 2 \mathrm{CH}_{3} \mathrm{COOH}+2 \mathrm{CO}_{2}+4 \mathrm{H}_{2}
\end{aligned}
$$

$$
\begin{aligned}
& \mathrm{CH}_{3} \mathrm{CH}_{2} \mathrm{OH}+2 \mathrm{H}_{2} \mathrm{O} \stackrel{\text { Enzymes }}{\longleftrightarrow} \\
& \mathrm{CH}_{3} \mathrm{COO}^{-}+2 \mathrm{H}_{2}+\mathrm{H}^{+}
\end{aligned}
$$

Methanogenesis. The microorganisms responsible for this phase are physiologically united as methane producers in anaerobic digestion [10]. Although methanogens consume acetic acid or $\mathrm{H}_{2}$ as the available substrates in their natural environment to produce methane/biomethane $(\mathrm{CH} 4)$ [29] other available substrates also include formate, methanol, methylamines, and carbon monoxides which are also converted to methane. Some of the bioreactions are illustrated as equations 8-12 [10,40]. Waste stabilization is then accomplished when methane gas and carbon dioxide are produced.

$$
\begin{aligned}
& \mathrm{CO}+\frac{1}{2} \mathrm{H}_{2} \mathrm{O} \stackrel{\text { Methanogens }}{\longrightarrow} \frac{1}{4} \mathrm{CH}_{4}+\frac{3}{4} \mathrm{CO}_{2} \\
& \mathrm{CO}_{2}+4 \mathrm{H}_{2} \stackrel{\text { Methanogens }}{\longrightarrow} \mathrm{CH}_{4}+2 \mathrm{H}_{2} \mathrm{O} \\
& 2 \mathrm{C}_{2} \mathrm{H}_{5} \mathrm{OH}+\mathrm{CO}_{2} \stackrel{\text { Methanogens }}{\longrightarrow} \\
& \mathrm{CH}_{4}+2 \mathrm{CH}_{3} \mathrm{COOH} \\
& \mathrm{CH}_{3} \mathrm{COOH} \stackrel{\text { Methanogens }}{\longrightarrow} \mathrm{CH}_{4}+\mathrm{CO}_{2} \\
& \mathrm{HCO}_{3}^{-}+4 \mathrm{H}_{2}+\mathrm{H}^{+} \stackrel{\text { Methanogens }}{\longrightarrow} \\
& \mathrm{CH}_{4}+3 \mathrm{H}_{2} \mathrm{O}
\end{aligned}
$$

The phases of anaerobic digestion and some of the microorganisms that take part in the anaerobic digestion as related by some authors in literature are summarized in Table 1.

Table 1 - Summary of phases and the key microorganisms and their roles in the AD processes

\begin{tabular}{|l|l|l|c|}
\hline \multicolumn{1}{|c|}{ Phase } & \multicolumn{1}{|c|}{ Microorganism } & \multicolumn{1}{c|}{ Role } & Author \\
\hline Hydrolysis & Bacteriodes, Clostridium, and Acetivibrio & $\begin{array}{l}\text { Breaks down complex substrates to } \\
\text { monomers and dimers }\end{array}$ & {$[17]$} \\
\hline Acidogenesis & $\begin{array}{l}\text { Clostridium, Peptococcus, Selenomonas, } \\
\text { Campylobacter, and Bacteroides }\end{array}$ & $\begin{array}{l}\text { Converts monomers and dimers into } \\
\text { volatile fatty acids, short chain organic } \\
\text { acids and alcohols. }\end{array}$ & {$[10]$} \\
\cline { 2 - 4 } & $\begin{array}{l}\text { Enterobacterium, Acetobacterium and } \\
\text { Eubacterium }\end{array}$ & $\begin{array}{l}\text { Converts monomers and dimers into } \\
\text { volatile fatty acids, short chain organic } \\
\text { acids and alcohols. }\end{array}$ & {$[16]$} \\
\hline Acetogenesis & $\begin{array}{l}\text { Syntrophomonas, Syntrophus, Clostrid- } \\
\text { ium, and Syntrobacter }\end{array}$ & $\begin{array}{l}\text { Converts the volatile fatty acids and the } \\
\text { alcohols to acetates, hydrogen, and car- } \\
\text { bonic anhydride }\end{array}$ & {$[17,39]$} \\
\hline Methanogenesis & $\begin{array}{l}\text { Methanosarcina spp. And Methanothrix } \\
\text { spp. }\end{array}$ & Converts acetates to methane & {$[17]$} \\
\cline { 2 - 4 } & $\begin{array}{l}\text { Methanobacterium, Methanococcus, } \\
\text { Methanogenium and Methanobrevibacter }\end{array}$ & Converts hydrogen to Methane & {$[39,42]$} \\
\hline
\end{tabular}




\section{RESULTS AND DISCUSSION}

Bio-fertilizer as the name implies, is a fertilizer that is made up of biological components, living organisms that synthesize the atmospheric plant nutrient in the soil or in the plant body, or create such an atmosphere in the soil or in the medium (in which the organisms are kept) which are helpful for the plants [45]. Bacterial biofertilizers can improve plant growth through several mechanisms: (1) the synthesis of plant nutrients or phytohormones, which can be absorbed by plants, (2) the mobilization of soil compounds, making them available for the plant to be used as nutrients, (3) the protection of plants under stressful conditions, thereby counteracting the negative impacts of stress, or (4) defense against plant pathogens, reducing plant diseases or death [14]. It is worthy to note, that bacteria in bio-fertilizers have specific purpose such as fixation of macro elements. Azotobacter, Azospirillum, Acetobacter are the most important bio-fertilizers for nitrogen fixation, while Bacillus sp. and Aspergillus sp. are important for phosphate solubilization and other soil mineral nutrients [34] as shown in Figure 2.

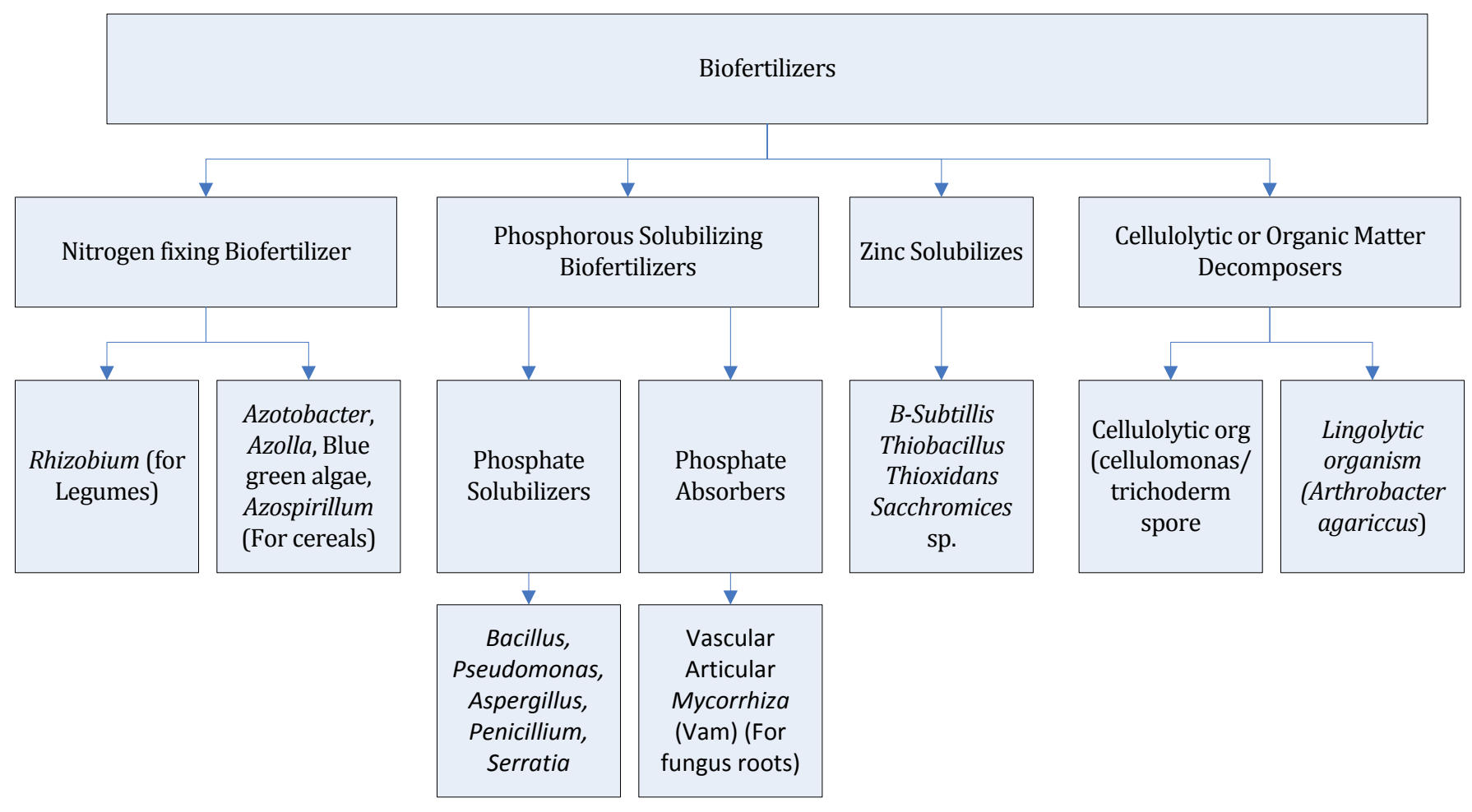

Figure 2 - Simplified classification of bio-fertilizers

Bio-fertilizers fix atmospheric nitrogen in the soil and root nodules of legume crops and makes them available to the plants. They solubilize the insoluble forms of phosphate like tricalcium, iron, and aluminum phosphates into available forms, scavenge phosphates from soil layers and they also produce hormones and anti-metabolites which promote root growth. Bio-fertilizers decompose organic matter and help in mineralization of soil. After application to the soils or seeds, they increase the availability of the nutrients and improves the yield by 10 to $20 \%$ without adversely affecting the soil and environment [37].
The most common technologies for optimizing the products of anaerobic digestion include the pretreatment of the substrates, biological approaches, co-digestion of substrates with other wastes, and the use of serial digesters [5].

There are several microorganisms that act as biofertilizers, some of which are discussed briefly in this section.

Nitrogen-fixing bio-fertilizers. Rhizobium. Rhizobium seems to be the best nitrogen-fixing biofertilizers when compared to other groups of microorganisms of similar function. The family 
name is Rhizobiaceae, they are symbiotic in nature, fixes nitrogen $50-100 \mathrm{~kg} / \mathrm{ha}$ in association with legumes only and it is useful for pulse legumes like chickpea, red-gram, pea, lentil, black gram, etc [28]. The bacteria infect the legume root and form root nodules within which they reduce molecular nitrogen to ammonia which is utilized by the plant to produce valuable proteins, vitamins and other nitrogen-containing compounds [34].

Nitrogen-fixing bio-fertilizers. Azotobacter. It is an important and well-known free-living nitrogenfixing aerobic bacterium. It belongs to the family Azotobacteriaceae, aerobic and heterotrophic in nature. Azotobacters are present in neutral or alkaline soils and are used as bio-fertilizers for all non-leguminous plants especially rice, cotton, vegetables, etc. [28]. One of the most common member of the several species of Azotobacter, which is $A$. chroococcum is the dominant inhabitant in most fertile soils capable of fixing $\mathrm{N}_{2}$ (2$15 \mathrm{mg} \mathrm{N}$ fixed/g of carbon) in culture media although lack of organic matter in the soil is a limiting factor for the proliferation of Azotobacter in the soil [34]

Nitrogen-fixing bio-fertilizers. Azospirillum. Belongs to family Spirilaceae, heterotrophic and associative in nature. Apart from their nitrogen fixability of about $20-40 \mathrm{~kg} / \mathrm{ha}$, they are also capable of regulating plant growth. Other species under this genus such as A.amazonense, A.halopraeferens, A.brasilense, although the worldwide distribution and benefits of inoculation have only been proved mainly with the A. lipoferum and A. brasilense. The Azospirillum form associative symbiosis with various plants particularly those having the $\mathrm{C}_{4}$-dicarboxylic mechanism of photosynthesis (Hatch and Slack pathway), because they grow and fix nitrogen on salts of organic acids such as malic, aspartic acid. Thus, it is mainly recommended for cereals and sugarcanes (Roychowdhury et al., 2014).

Nitrogen-fixing bio-fertilizers. Blue-Green Algae (Cyanobacteria) and Azolla. These belong to eight different families, phototrophic in nature and produce auxin, indoleacetic acid and gibberellic acid, fix 20-30 kg N/ha in submerged rice fields as they are abundant in paddy, $\mathrm{N}_{2}$ is the key input required in large quantities for low land rice production. Soil $\mathrm{N}_{2}$ and Bacterial Nitrogen Fixer (BNF) by associated organisms are major sources of $\mathrm{N}_{2}$ for low land rice. The $50-60 \% \mathrm{~N}_{2}$ requirement is met through the combination of miner- alization of soil organic $\mathrm{N}_{2}$ and BNF by free-living and rice plant-associated bacteria [28].

Phosphorous solubilizing/absorbing bio-fertilizers. The discovery of naturally occurring rhizospheric phosphorus solubilizing microorganism (PSM) can be traced back to the year 1903 [24]. Various studies have examined the possibility of a wide range of bacterial species to solubilize insoluble inorganic phosphate compounds example: tricalcium phosphate, dicalcium phosphate, hydroxyapatite, and rock phosphate [22]. The action of solubilizing inorganic phosphorus is as a result of the activities of low molecular weight organic acids which are produced by a variety of soil bacteria, on the other hand, the mineralization of organic phosphorus comes into existence through the synthesis of a variety of different phosphatases, catalyzing the hydrolysis of phosphoric esters with both phosphate solubilization and mineralization/absorption mostly coexisting in the same bacterial strain [35]. Among the bacterial genera with this capacity are Pseudomonas, Bacillus, Rhizobium, Burkholderia, Achromobacter, Agrobacterium, Microccocus, Aereobacter, Flavobacterium, and Erwinia (see Figure 2). There are considerable populations of phosphate solubilizing bacteria in soil and in plant rhizospheres. These include both aerobic and anaerobic strains, with a prevalence of aerobic strains in submerged soils. A considerably higher concentration of phosphate solubilizing bacteria is commonly found in the rhizosphere in comparison with non-rhizosphere soil [28].

\section{Merits and demerits of bio-fertilizers}

Bio-fertilizers as good as it seems also have various advantages and disadvantages. The preceding section discusses the merits and demerits of bio-fertilizer to both humans, animals, and plants.

Bio-fertilizers have numerous advantages to both humans, animals, and plants. Biofertilizers can mobilize nutrients that favor the development of biological activities in soils. This helps in the provision of food supply and as a result, enhances the maintenance of plant health through the addition of balanced nutrients. Biofertilizers also help promote the development of mycorrhizal associations, which increases the availability of phosphorus (P) on the soil. Plantar diseases can be eliminated by biofertilizer application and the 
soil nutrients' capacity exchange is also improved [8]. Bio-fertilizer increases crop yield by $20-30 \%$ and replace chemical nitrogen and phosphorus by $25 \%$ by stimulating plant growth and biologically activating and or restoring the natural soil fertility. It also helps in building up the soil fertility in a long term effect, apart from being ecofriendly thereby posing no damage to the environment, it is also cost-effective [15]. Biofertilizers reduce dependence upon expensive petroleum sources of chemical fertilizers, they are also cheap, easy-to-use as an alternative to manufactured petrochemical products [13].

Bio-fertilizers are difficult to store and are plantspecific i.e. some of the bio-fertilizers work best when applied to a specific class of plants. For example, those that give the best results when applied to cereals may perform woefully when applied to leguminous plants. In addition, the acceptability of bio-fertilizers has been rather low chiefly because they do give immediate and spectacular output results and may require high skills in both production and application [15]. Excessively acidic or alkaline soils also hamper successful growth of the beneficial microorganisms; moreover, they are less effective if the soil contains an excess of their natural microbiological enemies. Shortages of particular strains of microorganisms or of the best growing medium reduce the availability of some bio-fertilizers [13]. Compost products have highly variable concentrations of nutrients. In addition, implementation costs are higher than those of certain chemical fertilizers. Accumulation of salts, heavy metals, and nutrients in the soil may occur due to the extensive and long-term application of biofertilizers. In addition, large volumes may be required for land applications due to low nutrient content in comparison to chemical fertilizers [8].

Co-digestion is a technique in which two substrates are anaerobically digested for biogas production, this helps in improving the reliability of feedstock to the bioreactor and also helps in dilution of toxic substances which may be present in a single nutrient source, nutrient balance, synergistic effects on microorganisms, increase in a load of biodegradable organic matter and also improve methane yield per unit of digester volume [41]. When only one single substrate is used for anaerobic digestion, it is extremely undesirable as it contains a high nitrogen content, which inhibits the growth of bacteria during anaerobic digestion, thus leading to the reduction in methane production [9], thus co-digestion helps over- comes $\mathrm{C} / \mathrm{N}$ ratio imbalances in single digestion substrates [47].

Bio-hydrogen production from Specified Risk Materials (SRM) co-digested with cattle manure was studied and then it was concluded that hydrogen production may not be feasible on an industrial scale due to the reduction in hydrogen production as the levels of SRM increases [16]. A mathematical view on co-digestion was studied in 2010, the technique was modelled using General Integrated Solid Waste Co-digestion (GISCOD) to assist in plant design and codigestion operation. The tool was compiled in MATLAB which is accessed through MATLAB Simulink and toolboxes, the tool helped in overcoming the complexities and difficulties encountered in the optimization of the various conditions needed for effective digestion when feeding the digester with more than one feedstock [46]. When the effect of co-digestion of cow dung with rice chaff, rice straw and rice husk in biogas production using anaerobic digestion was studied, the combination of rice chaff/cowdung gave the best result, the cumulative gas production obtained from the three substrates ((1) Rice chaff / cow dung (2) Rice straw/ cow dung and (3) Rice husk/cow dung) was $3.8,3.4$ and $1.5 \mathrm{~m}^{3}$ respectively [44].

Enhanced biogas production from poultry droppings using corn-cob and waste paper as cosubstrates were studied by [7], it was deduced that poultry droppings plus treated co-substrates gave a cumulative average biogas volume of $6454 \mathrm{~cm}^{3}$ (with a rate of $215.1 \mathrm{~cm}^{3}$ day $^{-1}$ ) although no much information was available about the digestate. Authors [9] studied the potentials of co-digestion of rice straw with swine manure. The mixture is made in the composition of 2,3 and $4 \%$ total solids. Rice straw (RS) generated the highest methane production at $3 \%$ total solids (TS) which was around $(1814 \pm 47.43) \mathrm{ml}$, wherein this concentration, it had $\mathrm{C} / \mathrm{N}$ ratio at 10.6:1. The study, however, was silent about the quantity, quality of the digestates derived from these mixtures. A biogas aggregate of 156.25 litres of with $52.3 \%$ methane was realized after 75 days with an input slurry weight of $35 \mathrm{~kg}$ (6:1algae/rice husk) when rice husks and algae where co-digested using a metal Fixed-Dome biodigester at a temperature range of 29-33$45^{\circ} \mathrm{C}$ [32], however, the digestive would possibly have been a good soil nutrient but was not accounted for since it was not the point of interest in the work. A study carried out to determine the 
optimum conditions for bio-fertilizer production from the co-digestion of sewage and sawdust shows that the production was at optimum at a weight ratio of 5:1, a co-digestion period of 22.5 days with a moisture content of $45 \%$ [20].

Temperature is the most important parameter to be considered in anaerobic digestion. Different species of methanogens function optimally in three different temperature ranges: the species active between $45-60{ }^{\circ} \mathrm{C}$ is known as the thermophiles, those functions within the temperature range of $20-45^{\circ} \mathrm{C}$ called the mesophiles and those that are only active below $20^{\circ} \mathrm{C}$ called the psychrophiles [11]. The mesophilic temperature range was used by [4] to reduce the pathogen count from the bio-fertilizer produced from codigestion of cow dung and chicken droppings. Authors [33] developed models for predicting E. coli inactivation and survival in anaerobic digestion and was able to deduce incubation periods at different temperatures, such that the incubation periods at 25,37 , and $52.5^{\circ} \mathrm{C}$, were 61,41 , and 28 days respectively.

The carbon-nitrogen $(\mathrm{C} / \mathrm{N})$ ratio represents the relationship between the amount of carbon and nitrogen present in organic materials and is an important indicator for controlling biological treatment systems, optimum $\mathrm{C} / \mathrm{N}$ ratios in anaerobic digesters are between 20 and 30. A high $\mathrm{C} / \mathrm{N}$ ratio is an indication of rapid consumption of nitrogen by the methanogens and results in lower biogas production. On the other hand, a lower $\mathrm{C} / \mathrm{N}$ ratio causes ammonia accumulation and $\mathrm{pH}$ values exceeding 8.5 , which is toxic to methanogenic bacteria [30, 47], although recent studies have indicated that for biogas production, the $\mathrm{C} / \mathrm{N}$ ratio plays no important role [18]. The unbalanced nutrients are regarded as an important factor limiting anaerobic digestion of organic wastes, thus when the choice is for higher quality digestates (bio-fertilizers), to improve the nutrient level and $\mathrm{C} / \mathrm{N}$ ratios, co-digestion of organic mixtures is employed [3].

A variety of $\mathrm{pH}$ values good for anaerobic digestion has been reported by various studies. In the absence of any other factor, the $\mathrm{pH}$ value alone can be used to check digester environment and it was found that gas production is often highest when the $\mathrm{pH}$ is between 6.8 and 7.2 beyond these limits, digestion proceeds with less efficiency [21, 23]. The optimal $\mathrm{pH}$ values for the acidogenesis and methanogenesis stages are different. During acidogenesis, acetic, lactic and propionic acids are formed and, thus the pH falls [30]. When the $\mathrm{pH}$ falls to 6 and below, the efficiency drops rapidly and acidic conditions are produced which become inhibitory to methanogenic (methane producing) bacteria while at a $\mathrm{pH}$ of 7.0 there is a balance in the population of the acidogenic (acid producing) and methanogenic bacteria which help to convert the acids generated during anaerobic digestion into biogas [21].

The moisture content (solid water content) plays a vital role in co-digestion. There are three different ranges of solid content: low solid (LS) AD systems contain less than $10 \%$ Total Solid (TS), medium solid (MS) from 15-20\% and high solid systems (HS) range from 22-40\%. When increasing the total solid content, the volume of the digester decreases, due to lower water requirements [30]. High moisture contents usually facilitates the anaerobic digestion; however, it is difficult to maintain the same availability of water throughout the digestion cycle since the water quantity drops to a lower level as the process of anaerobic digestion proceeds although high moisture contents are likely to affect the process performance by dissolving the readily degradable organic matter [23].

Digestate also known as bio-fertilizer is the second product aside biogas from a biodigester which may be solid or liquid depending on the technology used, and contains a high proportion of mineral nitrogen (N) especially in the form of ammonium which is available for plants, it also contains other macronutrients such as $\mathrm{N}, \mathrm{P}, \mathrm{K}, \mathrm{Ca}$, $\mathrm{S}$ and $\mathrm{Mg}$ and microelements such as $\mathrm{B}, \mathrm{Cl}, \mathrm{Mn}$, $\mathrm{Fe}, \mathrm{Zn}, \mathrm{Cu}$, Mo and Ni necessary for plant growth and soil stabilization which depends widely on the characteristics of the substrates and the operation and technology of the biodigester [36]. In addition, it may contain some living microorganisms that influence the biological, chemical and physical properties of the soil [27]. Digestates may also contain some stubborn pathogens that were present in substrates such as farm wastes, slaughterhouse wastes and may not be removed by the process of anaerobic digestions via mesophilic temperature range. Some of these pathogens include Listeria, Salmonella, Escherichia coli, Mycobacterium, Clostridium, Campylobacter, and Yersinia with Salmonella being a major culprit which is of a major health concern $[19,36]$. Table 2 shows some properties of digestates from different substrates via different digestion processes. 
Table 2 - Characteristics of Digestates from different substrates

\begin{tabular}{|l|c|c|c|c|c|}
\hline \multicolumn{1}{|c|}{ Substrate type } & $\begin{array}{c}\text { Substrate, } \\
\mathrm{pH}\end{array}$ & $\begin{array}{c}\text { Digestate, } \\
\mathrm{pH}\end{array}$ & $\begin{array}{c}\text { Total } \\
\text { Nitrogen }\end{array}$ & $\begin{array}{c}\text { Total } \\
\text { Phosphorus }\end{array}$ & $\begin{array}{c}\text { Digestion } \\
\text { process }\end{array}$ \\
\hline Liquid cattle Manure & 6.9 & 7.6 & $4.27(\% \mathrm{DM})$ & $0.66(\% \mathrm{DM})$ & Mesophilic* \\
\hline $\begin{array}{l}\text { Energy crops + Cow manure + } \\
\text { Industrial wastes (Agro) }\end{array}$ & 4.8 & 8.7 & $\begin{array}{c}110(\mathrm{~g} / \mathrm{kg} \\
\mathrm{TS})\end{array}$ & $\begin{array}{c}11.79(\mathrm{~g} / \mathrm{kg} \\
\mathrm{TS})\end{array}$ & Thermophilic $^{*}$ \\
\hline Dairy Cow Slurry & 7.4 & 7.9 & $\begin{array}{c}3.6(\mathrm{~g} / \mathrm{kg} \\
\text { fresh wt) }\end{array}$ & - & Mesophilic $^{* *}$ \\
\hline Cowdung + Water melon & 5.8 & 7.2 & $25(\mathrm{mg} / \mathrm{L})$ & $5.2(\mathrm{mg} / \mathrm{L})$ & Mesophilic $* * *$ \\
\hline
\end{tabular}

Notes: * $-[26] ; * \star-[36] ; * \star \star-[19]$.

\section{CONCLUSION}

The need to improve the productivity in agricultural sectors of most African countries cannot be overemphasized. This is the origin of the vested interest in having more information about mechanisms, factors, types and various issues surrounding bio-fertilizers.

Bio-fertilizer is one of the products of anaerobic digestion which takes place in the absence of Oxygen. In this paper, biodigestion was classified with respect to the choice of either inoculating the substrates or not before feeding it to the biodigester. Also, various mechanisms in the digestion process which include hydrolysis, acido- genesis, acetogenesis, and methanogenesis were identified as discussed by different authors in the field, the pathways were illustrated with chemical equations and various microorganisms that take part in the anaerobic process were mentioned and tabulated. The types of bio-fertilizers, merits and demerits and also the difference between bio-fertilizers and inorganic fertilizers were comprehensively discussed. The current trend on the application of the co-digestion technique to improve the yield, nutrient, and safety of bio-fertilizers and also the recent progression in the field of co-digestion technique was mentioned.

\section{REFERENCES}

1. Adekunle, K. F., \& Okolie, J. A. (2015). A Review of Biochemical Process of Anaerobic Digestion. Advances in Bioscience and Biotechnology, 06(03), 205-212. doi: 10.4236/abb.2015.63020

2. Akwaka, J. C., Kukwa, D. T., \& Mwekaven, S. S. (2014). Preliminary Study on Co-Digestion of Cow Manure with Pretreated Sawdust for Production of Biogas and Biofertilizer. International Journal of Science and Technology, 3(4), 222-228.

3. Alemayehu, G. (2016). Co-digestion of municipal organic wastes with night soil and cow dung for biogas production: A Review. African Journal of Biotechnology, 15(2), 32-44. doi: 10.5897/ajb2015.14705

4. Alfa, M. I., Adie, D. B., Igboro, S. B., Oranusi, U. S., Dahunsi, S. O., \& Akali, D. M. (2014). Assessment of biofertilizer quality and health implications of anaerobic digestion effluent of cow dung and chicken droppings. Renewable Energy, 63, 681-686. doi: 10.1016/j.renene.2013.09.049

5. Andriani, D., Wresta, A., Atmaja, T. D., \& Saepudin, A. (2013). A Review on Optimization Production and Upgrading Biogas Through CO2 Removal Using Various Techniques. Applied Biochemistry and Biotechnology, 172(4), 1909-1928. doi: 10.1007/s12010-013-0652-x

6. Aragaw, T., Andargie, M., \& Gessesse, A. (2013). Co-digestion of cattle manure with organic kitchen waste to increase biogas production using rumen fluid as inoculums. International Journal of Physical Sciences, 8(11), 443-450.

7. Aremu, M. O., \& Agarry, S. E. (2013). Enhanced biogas production from poultry droppings using corncob and waste paper as co-substrate. International Journal of Engineering Science and Technology, 5(2), 247-253. 
8. Carvajal-Muñoz, J. S., \& Carmona-Garcia, C. E. (2012). Benefits and limitations of biofertilization in agricultural practices. Retrieved March 20, 2019, from http://www.lrrd.org/lrrd24/3/carv24043.htm

9. Cheng, J. J., Liu, Z., Gontupil, J., \& Kwon, O. (2014). Anaerobic co-digestion of rice straw and digested swine manure with different total solid concentration for methane production. International Journal of Agricultural and Biological Engineering, 7(6), 79-90.

10. Chou, D. (2015). Infrastructure. Practical Guide to Clinical Computing Systems, 39-70. doi: 10.1016/b978-0-12-420217-7.00004-3

11. Deepanraj, B., Sivasubramanian, V., \& Jayaraj, S. (2014). Biogas Generation through Anaerobic Digestion Process- An Overview. Research Journal of Chemistry and Environment, 18(5), 80-93.

12. Dobre, P., Nicolae, F., \& Matei, F. (2014). Main factors affecting biogas production - an overview. Romanian Biotechnological Letters, 19(3), 9283-9296.

13. Farnen, K. (2012). Advantages and Disadvantages of Biofertilizers. Retrieved April 30, 2017, from https://www.hunker.com/13404698/advantages-and-disadvantages-of-biofertilizers

14. García-Fraile, P., Menéndez, E., \& Rivas, R. (2015). Role of bacterial biofertilizers in agriculture and forestry. AIMS Bioengineering, 2(3), 183-205. doi: 10.3934/bioeng.2015.3.183

15. Ghumare, V., Rana, M., Gavkare, O., \& Khachi, B. (2014). Bio-Fertilizers- Increasing Soil Fertility and Crop Productivity. Journal of Industrial Pollution Control, 30(2), 199-201.

16. Gilroyed, B. H., Li, C., Hao, X., Chu, A., \& McAllister, T. A. (2010). Biohydrogen production from specified risk materials co-digested with cattle manure. International Journal of Hydrogen Energy, 35(3), 1099-1105. doi: 10.1016/j.ijhydene.2009.11.072

17. Goswami, R., Chattopadhyay, P., Shome, A., Banerjee, S. N., Chakraborty, A. K., Mathew, A. K., \& Chaudhury, S. (2016). An overview of physico-chemical mechanisms of biogas production by microbial communities: a step towards sustainable waste management. 3 Biotech, 6(1). doi: 10.1007/s13205-016-0395-9

18. Guarino, G., Carotenuto, C., Cristofaro, F. di, Papa, S., Morrone, B., \& Minale, M. (2016). Does the C/N ratio really affect the Bio-methane Yield? A three years investigation of Buffalo Manure Digestion. Chemical Engineering Transactions, 49, 463-468.

19. Hassan, D. U., \& Abdulsalam, S. (2017). Assessement of Bio-fertilizer Quality of Anaerobic Digestion of Watermelon Peels and Cow Dung. Chemical and Biomolecular Engineering, 2(3), 135-141.

20. Igbokwe, P. K., Asadu, C. O., \& Okpe, E. C. (2015). Manufacture of Bio Fertilizer by Composting Sawdust and Other Organic Waste. International Journal of Novel Research in Physics Chemistry \& Mathematics, 2(3), 6-15.

21. Iortyer, H. A., Ibrahim, J. S., \& Kwaghger, A. (2012). Effect of Mixing Ratio of Cattle and Piggery Dung on Biogas Generation. International Journal of Environment and Bioenergy, 1(3), 162-169.

22. Karpagam, T., \& Nagalakshmi, P. K. (2014). Isolation and characterization of Phosphate Solubilizing Microbes from Agricultural soil. International Journal of Current Microbiology and Applied Sciences, 3(3), 601-614.

23. Khalid, A., Arshad, M., Anjum, M., Mahmood, T., \& Dawson, L. (2011). The anaerobic digestion of solid organic waste. Waste Management, 31(8), 1737-1744. doi: 10.1016/j.wasman.2011.03.021

24. Khan, A. A., Jilani, G., Akhtar, M. S., Saqlan Naqvi, S. M., \& Rasheed, M. (2009). Phosphorus Solubilizing Bacteria: Occurrence, Mechanisms and their Role in Crop Production. Journal of Agriculture and Biological Sciences, 1(1), 48-58.

25. Lawal, A. A., Dzivama, A. U., \& Wasinda, M. K. (2016). Effect of inoculum to substrate ratio on biogas\&nbsp;production of sheep paunch manure. Research in Agricultural Engineering, 62(1), 8-14. doi: 10.17221/30/2014-rae 
26. Lukehurst, C. T., Frost, P., \& Al-Saedi, T. (2010). Utilisation of digestate from biogas plants as biofertiliser. Retrieved from

https://energiatalgud.ee/img_auth.php/4/46/IEA_Bioenergy._Utilisation_of_digestate_from_bio gas_plants_as_biofertiliser._2010.pdf

27. Makádi, M., Tomócsik, A., \& Orosz, V. (2012). Digestate : A New Nutrient Source - Review. In S. Kumar (Ed.), Biogas (pp. 295-310). Retrieved from http://cdn.intechopen.com/pdfswm/31331.pdf

28. Mishra, D., Rajvir, S., Mishra, U., \& Kumar, S. (2013). Role of Bio-Fertilizer in Organic Agriculture: A Review. Research Journal of Recent Science, 2, 39-41.

29. Mitchell, S. M., Kennedy, N., Ma, J., Yorgey, G., Kruger, C., Ullman, J. L., \& Frear, C. (2015). Anaerobic Digestion Effluents and Processes: the Basics. Retrieved from http://cru.cahe.wsu.edu/CEPublications/FS171E/FS171E.pdf

30. Monnet, F. (2003, November). An Introduction to Anaerobic Digestion of Organic Wastes. Retrieved from

http://www.biogasmax.co.uk/media/introanaerobicdigestion_073323000_1011_24042007.pdf

31. Neves, L., Oliveira, R., \& Alves, M. M. (2009). Co-digestion of cow manure, food waste and intermittent input of fat. Bioresource Technology, 100(6), 1957-1962. doi:

10.1016/j.biortech.2008.10.030

32. Onah, D. U., Offor, P. O., Ezekoye, B. A., \& Ezekoye, V. A. (2014). Characterization of Biogas Produced from Rice Husks and Algae using a Metal Fixed-Dome Biodigester. Global Journal of Science Frontier Research, 14(1) .

33. Pandey, P. K., \& Soupir, M. L. (2011). Escherichia coli inactivation kinetics in anaerobic digestion of dairy manure under moderate, mesophilic and thermophilic temperatures. AMB Express, 1(1), 18. doi: $10.1186 / 2191-0855-1-18$

34. Rana, R., Ramesh, \& Kapoor, P. (2013). Bio-Fertilizers and Their Role in Agriculture. Popular Kheti, 1(1), 56-61.

35. Rathi, M., \& Gaur, N. (2016). Phosphate solubilizing bacteria as biofertilizer and its applications. Journal of Pharmacy Research, 10(3), 146-148.

36. Risberg, K. (2015). Quality and function of anaerobic digestion residues. Retrieved from https://pub.epsilon.slu.se/12017/

37. Roychowdhury, D., Paul, M., \& Banerjee, S. K. (2014). A Review on the Effects of Biofertilizers and Biopesticides on Rice and Tea Cultivation and Productivity. International Journal of Science, Engineering and Technology, 2(8), 96-105.

38. Saidu, M., Yuzir, A., Salim, M. R., Salmiati, Azman, S., \& Abdullah, N. (2013). Influence of palm oil mill effluent as inoculum on anaerobic digestion of cattle manure for biogas production. Bioresource Technology, 141, 174-176. doi: 10.1016/j.biortech.2013.03.111

39. Schunurer, A., \& Jarvis, A. (2009). Microbiological Handbook for Biogas Plants. Retrieved from http://www.eac-

quality.net/fileadmin/eac_quality/user_documents/3_pdf/Microbiological_handbook_for_biogas _plants.pdf

40. Serna, E. (2009). Anaerobic Digestion Process. Retrieved March 19, 2017, from http://www.wtert.eu/default.asp?Menue=13\&ShowDok=12

41. Shah, F. A., Mahmood, Q., Rashid, N., Pervez, A., Raja, I. A., \& Shah, M. M. (2015). Co-digestion, pretreatment and digester design for enhanced methanogenesis. Renewable and Sustainable Energy Reviews, 42, 627-642. doi: 10.1016/j.rser.2014.10.053

42. Thauer, R. K., Kaster, A.-K., Seedorf, H., Buckel, W., \& Hedderich, R. (2008). Methanogenic archaea: ecologically relevant differences in energy conservation. Nature Reviews Microbiology, 6(8), 579591. doi: 10.1038/nrmicro1931 
43. University of Wisconsin Oshkosh. (2010, June 9). Biodigester Fact Sheet. Retrieved from https://www.uwosh.edu/sustainability/internal-documents/materials-by-topic/uwobiodigester-fact-sheet

44. Vivekanandan, S., \& Kamaraj, G. (2011). Effect of co-digestion of cow dung with rice chaff, rice straw and rice husk in biogas production using anaerobic digestion. International Research Journal of Biotechnology, 2(5), 114-118.

45. Youssef, M. M. A., \& Eissa, M. F. M. (2014). Biofertilizers and their role in management of plant parasitic nematodes . A review. Journal of Biotechnology and Pharmaceutical Research, 5(1), 1-6.

46. Zaher, U., Li, R., Pandey, P., Ewing, T., Frear, C., \& Chen, S. (2010). Development of Co-Digestion Software Models to Assist in Plant Design and Co-Digestion Operation. Retrieved from https://pdfs.semanticscholar.org/4a8e/da72a57ac498c50994d5b4f5c5f52a3881c0.pdf

47. Zhang, T., Liu, L., Song, Z., Ren, G., Feng, Y., Han, X., \& Yang, G. (2013). Biogas Production by CoDigestion of Goat Manure with Three Crop Residues. PLoS ONE, 8(6), e66845. doi: 10.1371/journal.pone.0066845

48. Zhang, Y., Banks, C. J., \& Heaven, S. (2012). Co-digestion of source segregated domestic food waste to improve process stability. Bioresource Technology, 114, 168-178. doi:

10.1016/j.biortech.2012.03.040 